\title{
The Effects of Effluent Discharged from Bottling Companies on Algal Composition in Kakuri Stream Kaduna, Nigeria
}

\author{
${ }^{*}$ S.K. Zaky and 2I.Y. Okpanachi \\ 1Department of Biological Sciences, Kaduna state University, Kaduna, Nigeria \\ 2Department of Botany, University of Lagos, Lagos, Nigeria \\ [ ${ }^{*}$ Corresponding author: E-mail: suziekuyet@gmail.com, D:+2348038500795]
}

\section{ABSTRACT}

This study determined the impact of soft drink effluent on algal composition in Kakuri stream, Kaduna South Local Government Area, Kaduna. Limnological studies of soft drink effluent were carried out for a period covering wet and dry seasons across three (3) sampling points code-named Stations A, B and C. Some physio-chemical parameters were analysed using standard methods. A total of 43 species were observed belonging to 5 families. Chlorophyceae and Cyanophyceae were the most abundant families across the three (3) stations. The total flora count was high during the dry season, 1965 cells than wet season, 1071 cells. The most dominant species were Euglena sp., Microcystis sp. and Oscillatoria sp. The pH of the three stations was more alkaline ( $\mathrm{pH}$ 8.1) but reduces slightly at stations $\mathrm{B}$ and $\mathrm{C}$ during the months of May $(\mathrm{pH}$ 5.2) and August ( $\mathrm{pH}$ 6.5). The biological oxygen demand (BOD) was relatively high across the stations, dissolved oxygen was generally low except for some months (December at station A and January at station B) that had its dissolved oxygen values above $5.00 \mathrm{mg} / \mathrm{l}$. Euglenophyceae showed positive correlation to conductivity and BOD, Chlorophyceae was positively correlated with BOD, Cyanophyceae showed positive relationship with $\mathrm{BOD}$ and dissolved oxygen, Charophyceae was positively correlated with dissolved oxygen, Bacillariophyceae showed positive correlation with $\mathrm{pH}$, temperature, phosphorus, BOD and dissolved oxygen. Effluent discharge and farmland run-off passed into the water body supports growth of dominant species indicating organic pollution, thus, poses a threat to the environment over a long period of time.

Keywords: Algae, Effluent, Biological oxygen demand, Dissolved oxygen.

\section{INTRODUCTION}

Algal succession in a given habitat depends on a number of environmental factors such as physical factors including light, temperature and space, Chemical factors such as nitrogen, $\mathrm{pH}$, phosphorus and salinity and biological factors for example organic matter. Rabalais (2002) reported that nitrogen or phosphorus sometimes limits autotrophic production of freshwater algae. The biodiversity of algal species also depends on its ability to adapt to environmental stress on exposure, which could affect its distribution and abundance between seasons. Increased nutrient level, shifts in nutrient ratios or both may lead to excessive algal growth and may result to a proliferation of a single species (Chia and Bako, 2008). According to Hsu et al. (2009) the type of algal composition is depends on the $\mathrm{pH}$ of water. Alarming growth rate of green algae in lakes and rivers are related to the increase in $\mathrm{pH}$ of polluted waters. Akomeah et al., (2010) stated that, algae being primary producers of the aquatic ecosystem occupy an important position in aquatic food chain and also producers of oxygen in the aquatic ecosystem. Change in the chemistry of the water could adversely affect the entire trophic levels. Effluent discharge in rivers from industries in Nigeria and the world at large could pose a serious threat in the diversity of algae. The distributions, abundance, species diversity, species composition of algae are used to assess the biological integrity of water body (Ajani, 2010, Kadiri, 2006). Although, their movement is controled by the water current, thus, they cannot escape pollution effects and this makes a good indicator of pollution in the environment. The aim of this work is to assess the effect of anthropogenic activities on algae 
composition of streams.

\section{MATERIALS AND METHODS \\ Study Area}

The study area is located in Kakuri district of Kaduna South Local Government Area, Kaduna State, Nigeria. Kakuri is an industrial zone where soft drinks, textiles and other industrial products are manufactured. The Kakuri stream is situated in the Local Government Area at Longitude: $10^{\circ}$ $28^{\prime} 0^{\prime \prime}$ North and Latitude: 07ㅇ 25' 0" East. The effluent studied included waste water discharge from Coca-Cola and Seven - Up bottling companies.

\section{Collection of Samples}

Effluent sample for physiochemical analysis were obtained between the hours of 9am - 11am monthly (April, 2011 - March, 2012) in 250ml plastic bottles with crew caps at three (3) sampling points; i.e. Station A (Coca-Cola bottling company waste water run-off), Station B (Seven - Up bottling company waste water run-off) and Station C (Confluence point of Coca-Cola and Seven - Up bottling company effluents).

\section{Collection of Algae}

The algae were collected by filtering of water through plankton net of mesh size $55 \mu \mathrm{m}$; the filtrate is then transferred into $20 \mathrm{ml}$ sample bottle and preserved in $4 \%$ formalin.

\section{Analysis of algal samples}

Identification was carried out using binocular microscope and reference on the identification of species were made to Lackey (1938), Patrick and Reimer (1966), Needham and Needham (1962), and Kadiri (1988, 1993 and 1996). Algal counts were carried out using the method of Verlencar and Desai (2004).

Analyses of physico-chemical properties

Temperature, $\mathrm{pH}$ and Conductivity were determined in-situ using a portable
HANNA/pH/EC/Temperature meter model 210. Dissolved Oxygen (DO) was estimated in-situ with HACH oxygen DO-5509 meter. Total Dissolved Solid (TDS) was determined using a handheld HACH TDS meter model 5358236. Nitrate was analysed using ultraviolet spectrophometric meter and Phosphate was analysed using stannous chloride method (APHA 1985).

Statistical analysis: Analysis of variance (ANOVA) was used to test for station differences in values of the physic-chemical parameters in the water. Correlation matrix was between various physico-chemical parameters and algal families. Data obtained from abundance of phytoplankton between dry and wet season was compared using Diversity Index

\section{RESULTS}

Algal composition was studied for the period of twelve (12) months from April 2011- March, 2012. Taxonomic listing of the observed algal species at Kakuri, Kaduna-Nigeria across three (3) stations $A, B, C$ is given in Table 2. A total of forty-three (43) genera belonging to five (5) families were identified during the study. The taxa Chlorophyceae and Cyanophyceae were most diverse classes represented by 23 and 13 genera respectively followed by Bacillariophyceae with 6 genera; the least was Charophyceae and Euglenophyceae 1 genera each. The maximum numbers of genera were found during the months of December, January, February and March (dry season) and August (wet season). The month with minimum number was July (wet season). The percentage of occurrence was Chlorophyceae at $45.42 \%$, Cyanophyceae at $35.60 \%$, Bacillariophyceae at $9.52 \%$, Euglenophyceae at $9.03 \%$ and Charophyceae at $0.43 \%$. The most dominant algal species were Euglena sp., microcystis sp. and oscillatoria sp. 
Nigerian Journal of Basic and Applied Science (June, 2019), 27(1): 25-33

Table 1: Physico-chemical properties determined in the dry and wet season of selected effluent points

\begin{tabular}{|c|c|c|c|c|c|c|c|c|c|}
\hline SEASON & STATIONS & MONTHS & $\mathrm{pH}$ & Temperature $^{0} \mathrm{C}$ & $\begin{array}{c}\text { Electrical } \\
\text { Conductivity }(\mu / \mathrm{cm})\end{array}$ & Nitrate & Phosphorus & $\begin{array}{c}\text { Biological } \\
\text { Oxygen } \\
\text { Demand } \\
\end{array}$ & $\begin{array}{l}\text { Dissolved } \\
\text { Oxygen }\end{array}$ \\
\hline \multirow[t]{22}{*}{ DRY } & $A$ & April & 7.2 & 30 & 249 & 1 & 2.3 & 4.9 & 3.1 \\
\hline & & Oct & 7.8 & 31 & 266 & 1 & 0.04 & 5.56 & 1.74 \\
\hline & & Nov & 7.6 & 31 & 419 & 1.2 & 0.07 & 5.6 & 2.3 \\
\hline & & Dec & 7.5 & 30 & 239 & 1.2 & 0.03 & 4.56 & 6.5 \\
\hline & & Jan & 7.5 & 30 & 239 & 1.2 & 0.75 & 4.6 & 2.18 \\
\hline & & Feb & 7.2 & 30 & 249 & 1 & 0.01 & 5.75 & 2.88 \\
\hline & & March & 7.5 & 31.5 & 239 & 1.4 & 2.5 & 4.95 & 4 \\
\hline & B & April & 7.3 & 31.3 & 240 & 1.1 & 2.2 & 5 & 3.6 \\
\hline & & Oct & 7.4 & 27.9 & 239 & 0.01 & 0.32 & 5.08 & 2.23 \\
\hline & & Nov & 8.1 & 27 & 364 & 0.06 & 0.56 & 4.5 & 2.15 \\
\hline & & Dec & 6.5 & 23.6 & 188 & 0.01 & 0.32 & 4.58 & 5.4 \\
\hline & & Jan & 7.3 & 30 & 239 & 0.01 & 0.91 & 5.23 & 2.19 \\
\hline & & Feb & 8 & 26.3 & 218 & 0.28 & 0.55 & 5.32 & 2.5 \\
\hline & & March & 8 & 31 & 241 & 0.03 & 0.12 & 5.78 & 3.8 \\
\hline & C & April & 7.5 & 31.5 & 238 & 2.08 & 2.4 & 5.25 & 3.4 \\
\hline & & Oct & 7.6 & 29.1 & 241 & 0.5 & 1.1 & 3.6 & 2 \\
\hline & & Nov & 7.9 & 29 & 390 & 0.62 & 0.6 & 4.6 & 4.2 \\
\hline & & Dec & 7.8 & 27 & 214 & 0.61 & 1.1 & 4.6 & 2.2 \\
\hline & & Jan & 7.4 & 29 & 243 & 0.6 & 1.1 & 4.9 & 2.2 \\
\hline & & Feb & 7.6 & 28 & 233 & 0.64 & 2.3 & 4.95 & 3.1 \\
\hline & & March & 7.6 & 31.5 & 245 & 0.56 & 1.25 & 5.43 & 3.4 \\
\hline & & Means $\pm S D$ & $7.54 \pm 0.353$ & $29.32 \pm 2.069$ & $258.71 \pm 58.034$ & $0.72 \pm 0.553$ & $0.98 \pm 0.870$ & $4.99 \pm 0.517$ & $3.10 \pm 1.201$ \\
\hline \multirow[t]{17}{*}{ WET } & $A$ & May & 7.8 & 31 & 266 & 1 & 1.1 & 4.8 & 3 \\
\hline & & June & 7.8 & 31.5 & 283 & 4 & 1.2 & 4.3 & 3.5 \\
\hline & & July & 7.5 & 31 & 263 & 4 & 1.1 & 4.4 & 3.3 \\
\hline & & Aug & 7.8 & 31 & 270 & 1 & 1.6 & 3.84 & 3.1 \\
\hline & & Sep & 8.1 & 29.4 & 641 & 6.3 & 1.57 & 4.4 & 2.73 \\
\hline & B & May & 6.8 & 26.5 & 223 & 0.1 & 2 & 4.9 & 3.5 \\
\hline & & June & 7 & 27.5 & 226 & 0.1 & 2.05 & 5 & 4 \\
\hline & & July & 6.8 & 26.5 & 224 & 0.09 & 1.12 & 4.96 & 3.72 \\
\hline & & Aug & 5.2 & 27 & 209 & 0.13 & 1.1 & 4.22 & 2.58 \\
\hline & & Sep & 6.7 & 25.6 & 558 & 1 & 1.1 & 5.15 & 1.74 \\
\hline & $C$ & May & 7.5 & 26 & 242 & 2.06 & 1.2 & 4.2 & 3.2 \\
\hline & & June & 7.5 & 29.5 & 245 & 2.07 & 1.6 & 4.85 & 4.01 \\
\hline & & July & 7.3 & 28.7 & 243 & 2.04 & 2.05 & 4.6 & 3.51 \\
\hline & & Aug & 6.5 & 29 & 239 & 0.56 & 2.05 & 6.9 & 2.84 \\
\hline & & Sep & 7.4 & 27.5 & 599 & 8.6 & 0.62 & 4.8 & 2.23 \\
\hline & & Means \pm SD & $7.18 \pm 0.722$ & $28.51 \pm 2.014$ & $315.40 \pm 149.098$ & $2.20 \pm 2.520$ & $1.43 \pm 0.451$ & $4.76 \pm 0.697$ & $3.13 \pm 0.635$ \\
\hline & & ANOVA between season & 0.57 & 0.252 & 0.121 & 0.013 & 0.074 & 0.257 & 0.925 \\
\hline
\end{tabular}


Zaky and Okpanachi: The Effects of Effluent Discharged from Bottling Companies on Algal.......

Table 2: Distribution of identified algal species in Station A, B and C from April, 2011- March, 2012

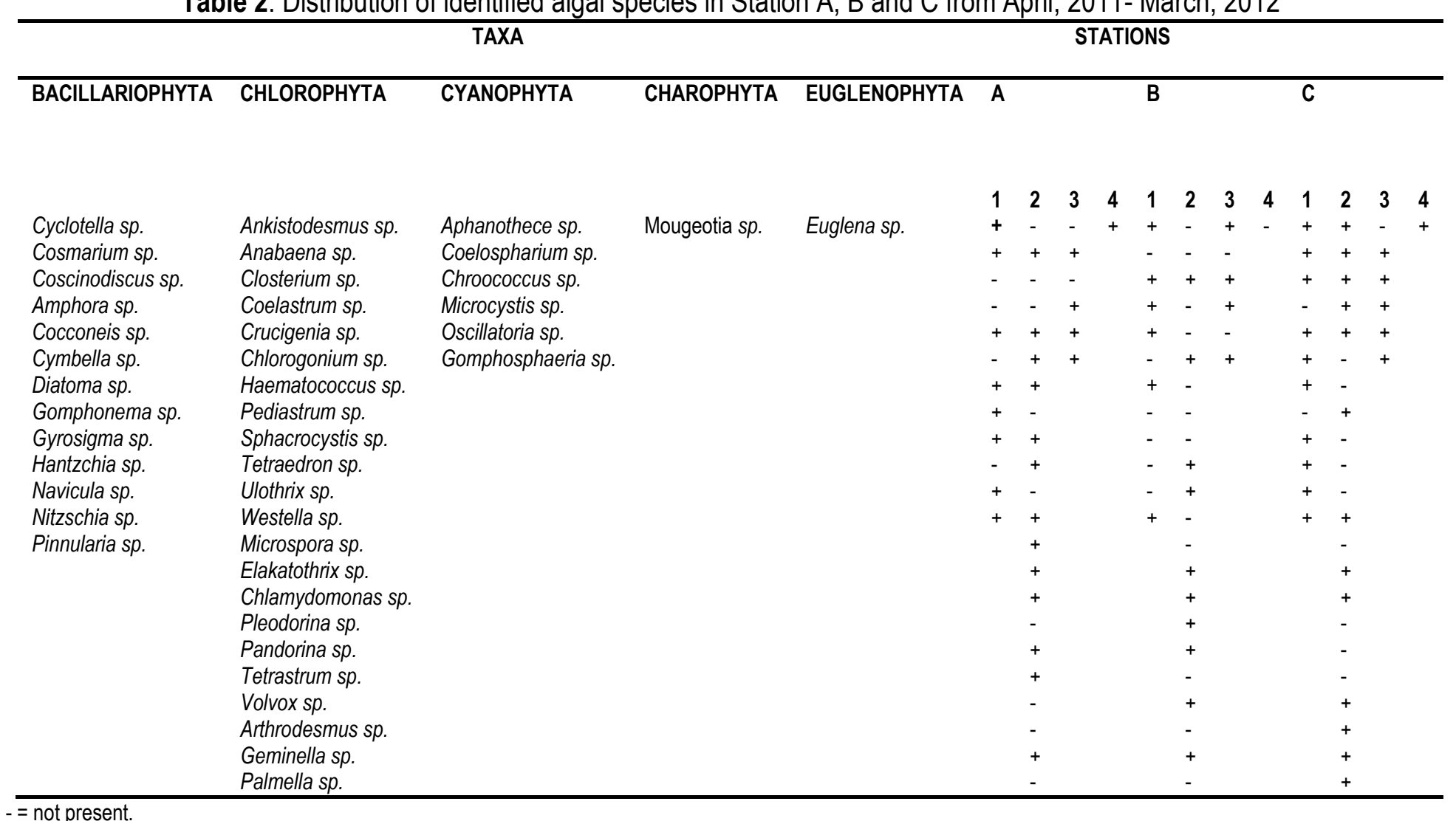

$+=$ present, $-=$ not present 
TABLE 3: Algal composition during wet season (May - October) and dry season (January.-April, November - December) across selected effluent points April, 2011- May, 2012

\begin{tabular}{lcccc}
\hline & \multicolumn{2}{c}{ Wet season } & \multicolumn{2}{c}{ Dry season } \\
\hline Taxon & Total & Frequency $(\%)$ & Total & Frequency \\
count & $(\%)$ \\
Bacillariophyceae & 135 & 12.61 & 326 & 16.59 \\
Chlorophyceae & 560 & 52.29 & 749 & 38.12 \\
Cyanophyceae & 270 & 25.21 & 758 & 38.58 \\
Charophyceae & 4 & 0.37 & 12 & 0.61 \\
Euglenophyceae & 102 & 9.52 & 120 & 6.11 \\
Total Count (cells mgl- ${ }^{-1}$ ) & 1071 & 100 & 1965 & 100 \\
\hline
\end{tabular}

Table 4: Biological Indices of Algal Composition In wet season ((May - October) and Dry Season (January-April, November - December) Across The Three (3) Stations

\begin{tabular}{lcc}
\hline $\begin{array}{l}\text { Diversity Indices/ } \\
\text { Season }\end{array}$ & $\begin{array}{c}\text { Wet } \\
\text { Season }\end{array}$ & $\begin{array}{c}\text { Dry } \\
\text { Season }\end{array}$ \\
\hline $\begin{array}{l}\text { Total Algal Count (Cells } \\
\text { Mgl-1) }\end{array}$ & 1071 & 1965 \\
Shannon_H & 1.192 & 1.235 \\
Simpson_1-D & 0.6381 & 0.6579 \\
Evenness_e & & \\
\hline
\end{tabular}

\section{DISCUSSION}

Silva (2005) reported that the overwhelming presence of Microcystis sp. in Shahpur dam especially in summer could be attributed to the presence of bright sunshine, isothermal water column and extensive catchment area draining calcium rich agriculture land. Physiological and behavioural flexibility of Microcystis sp. can accommodate environmental stresses better than most fast growing species and it is found to be an excellent example of phytoplankton in the tropics (Silva, 2004). This could explain perhaps the dominance of Euglena sp. and Oscillatoria spicrocystis $s p$. High number of Oscillatoria $s p$. and high percentage of Cyanophyceae is an indication of pollution in the water. This was in agreement with the findings of Pramila et al. (2008). This research finding is in line with the work of Odhiambo and Gichuki (1998) who reported that algae of Lake Baringo in Kenya were dominated by the Cyanophyta and Chlorophyta and that the lake is in a state of gradual deterioration of water quality. Khan et al. (1983), Kemdirim (2001) and Reynolds (1984) identified Chlorophyceae as the most abundant group in Nigeria fresh waters. The total number of flora count in dry season of 1965 was greater than that of wet season, 1071 (Table 3). Abowei et al. (2008) recorded more species of phytoplankton in wet season in the lower Sombreiro River, Niger Delta, Nigeria.

From the calculated result, Shannon-Weiner's, Simpson's and Evenness Indices value were high in the dry season than in the wet The relationship between species diversity and pollution status of aquatic ecosystem were classified as follows; $>3=$ clean water, $1-3=$ moderately polluted $<1=$ heavily polluted, which indicates that the stations were moderately polluted.

The mean and standard deviation of the different physico-chemical parameters of the three (3) stations during April 2011 - March, 2012 is presented in Table 1. The $\mathrm{pH}$ value of 7.2 was recorded in station A during the month of April, 


\section{Zaky and Okpanachi: The Effects of Effluent Discharged from Bottling Companies on Algal.......}

and $\mathrm{pH} 8.1$ was obtained in the month of September. On the other hand, the surface water temperature was low in the month of September $\left(29.4^{\circ} \mathrm{C}\right)$, and was high during months of March and June $\left(31.5^{\circ} \mathrm{C}\right)$. Conductivity was highest at the month of September and lowest during the month of December and January. Nitrate concentration was at a high during the month of September and was low at $0.01 \mathrm{mg} / \mathrm{l}$ in January to April and October to December. Phosphorus concentration was highest at the month of March and low in May and July. Biological oxygen demand was lowest at the month of February and the highest at the month of August. Dissolved oxygen was lowest in the month of September and highest in December.

At station $\mathrm{B} ; \mathrm{pH}$ was low in the month of August at 5.2 and at a high in November at 8.1. Surface water temperature was highest in April at $31.3^{\circ} \mathrm{C}$ and low in December at $23.6^{\circ} \mathrm{C}$. Conductivity was high during the month of September at 558 and low at December 188. Highest nitrogen concentration observed in station B was at the month of September at $1.00 \mathrm{mg} / \mathrm{l}$ and at low in June at $0.09 \mathrm{mg} / \mathrm{l}$. phosphorus concentration was at high during the month of April at $2.2 \mathrm{mg} / \mathrm{l}$ and low in march at $0.12 \mathrm{mg} /$. biological oxygen demand was at a low in the month of August at $4.22 \mathrm{mg} / \mathrm{l}$ and high at March at $5.78 \mathrm{mg} / \mathrm{l}$. dissolved oxygen was high at December at 5.4 $\mathrm{mg} / \mathrm{l}$ and low at September at $1.74 \mathrm{mg} / \mathrm{l}$.

At station $\mathrm{C}$; pH was low in August at 6.5 and high in November at 7.9. Surface water temperature was low in May at $26^{\circ} \mathrm{C}$ and high in April, March at $31.5^{\circ} \mathrm{C}$ each. Conductivity was highest at September at 599 and low in the month of December at 214. Highest nitrogen concentration was observed in the month of September at $8.6 \mathrm{mg} / \mathrm{l}$ and lowest in the month of October at $0.5 \mathrm{mg} / \mathrm{l}$. Low phosphorus concentration was observed in the month November at $0.6 \mathrm{mg} / \mathrm{l}$. and at high in February at $2.3 \mathrm{mg} / \mathrm{l}$. Biological oxygen demand was highest at $6.9 \mathrm{mg} / \mathrm{l}$ in the month of August and low in the month of October at $3.6 \mathrm{mg} / \mathrm{l}$. Dissolved oxygen was at low in October at $2.00 \mathrm{mg} / \mathrm{l}$ and high in November at $4.2 \mathrm{mg} / \mathrm{l}$. Analysis of variances of physico-chemical parameters across the three (3) stations between wet and dry season showed significant difference except for nitrate concentration that showed no significant difference between the seasons.

Correlation matrix between various physicochemical parameters and algal families are given in Table 6. Bacillariophyceae showed positive correlation with $\mathrm{pH}$, temperature, phosphorus, biological oxygen demand and dissolved oxygen. Chlorophyceae had negative relationship with $\mathrm{pH}$, temperature, electrical conductivity, nitrogen, dissolved oxygen and phosphorus but was positively correlated with biological oxygen demand. Cyanophyceae had a positive relationship with biological oxygen demand, dissolved oxygen but had negative relationship with other physico-chemical parameters. Charophyceae only had positive relationship with dissolved oxygen and negative relationship with other physico-chemical parameters. Euglenophyceae had a negative correlation with $\mathrm{pH}$, temperature, nitrogen, phosphorus and dissolved oxygen but had positive correlation with electrical conductivity and biological oxygen demand.

The water body is loaded by the effluent of seven up (7up) and Coka-cola bottle company. The mean surface water temperatures were high in all stations and nearly uniform. The changes in the temperature of the water body could be attributed to influence by the dilution of effluent and the intensity of sunlight in the months of the dry season and lower temperature during the months of rainy season could be implicated by surface water runoff into the stream and cloud cover since it is rainy season. Manoj and Pooj (2012) observed a similar trend of result in their work on a wetland affected by pulp and paper mill effluents, noted the difference in temperature which is attributed to the effluent and prevailing air-masses. The $\mathrm{pH}$ values recorded in the stream were within the expected range of inland 
water $(\mathrm{pH} 6.5-8.5)$ as reported by WHO, (2006). The high electrical conductivity in the wet season could be due to dilution effect of effluent and rain water with concentration of dissolved constituents. The noticeable increase in electrical conductivity in the dry season may be attributed to high evaporation process this resulted in the concentration of the ions in the water (Allan, 2001). The high values of nitrate and phosphorus in the wet season could be as a result of run-off of nutrients from agricultural lands, livestock and human waste from the catchment areas of the stream (Ezra, 2006). Dissolve oxygen (DO) values were high in the wet season than in dry season, could be due to the increased current flow that enables the dilution of atmospheric oxygen with the water. This agrees with the finding of Nirmal and Cini, (2011). The values of biochemical oxygen demand (BOD) were higher in station $A$ and $B$ during dry season than wet season. The high BOD concentration in dry season could be attributed to increase input of decomposes organic matter into the stream by effluent. The appreciable increase in BOD value in wet season could be due to increase input of organic matter into the stream through surface run-off (Essien-lbok et al.;2010).

Six major algal classes were present in the Kakuri stream, namely: Bacilloriophyceae (diatom), Chlorophyceae (green algae), Cyanophyceae (blue green algae), Chrysophyceae (golden algae) and Euglenophyceae (euglena). The present of these algal classes is typical of fresh water stream (Adakole et al.; 2002), representatives of these algal groups were identified in the lower Sombreiro river Niger Delta (Abowei et al.; 2008). Algae in each class are listed in Table 2. The class with the largest species composition was the Chlorophyceae followed by Cyanophyceae, Bacilloriophyceae. Chrysophyceae and Euglenophyceae were scare, represented by only one species each. Compare to coastal water system in the estuarine this diversity is relatively low (Onyema, 2007). The high density of 1965 cells $\mathrm{mgl}^{-1}$ ) in dry season could be due to sufficient light penetration into the water with its attendant high productivity. The low cells density during wet season could be associated with dilution by effluent and rainfall which flushed away algal materials by flood. The growth and dominant Chlorophyceae in the study area reflects the oligotrophic nature of the stream as also reported by Rafia et al. (2013). The change from green algae dominant to blue green algae is attributed to relatively higher temperature and lower values of conductivity (Jafari and Alavi, 2010); this indicates deterioration in water quality probably as a result of large amount of decomposing organic matter present in the stream. In the present study, $\mathrm{pH}$ was found to be at neutral range $(7.0-8.0)$ which support a good population of Bacilloriophyceae (Nirmal and Cini, 2011).The high growth of Chlorophyceae and Bacilloriophyceae has earlier been associated with high water temperature, phosphorus, nitrate and low DO (Rafia et al., 2013), the present findings support this view. The growth of blue green algae and euglenoides is enhancing by higher value of $\mathrm{pH}$. The present finding agrees with this view.

This study revealed that variation in abundance plankton can be best explained on environmental factors jointly influence. Thus, it may be concluded that the composition of algae is dependent on seasonal variation and load of pollutants directly or indirectly.

\section{CONCLUSION}

Algal diversity and abundance could be used as an important tool in monitoring changes across three (3) stations. The rich ecological heritage of the stream is being threatened by the current state of environment perturbation from industrial effluent, though some species were able to withstand this stressful situation. Kakuri stream supports growth of Euglena sp, Microcystis sp. and Oscillatoria $s p$. which is an indication of organic pollution. This could pose a threat to the environment over a long period of time. 


\section{REFERENCES}

Adakole, J.A, Balogun, J.K. and Lawal, F.A. (2002). Water quality Impacts Assessment Associatedwith an Urban Stream in Zaria, Nigeria. NISEB Journal, 2(3): $195-203$

Abowei, J.F., Tawari, C.C. and Hart, A.I. (2008): Phytoplankton and Physico-chemical Characteristics in the Lower Sombreiro River, Niger Delta, Nigeria. African Journal of Applied Zoology and Environmental Biology, 10:11-19.

Ajani, G.E. (2010). The biodiversity of phytoplankton community in selected parts of the Lagos Lagoon, Nigeria. Journal of Biological Sciences and Conservation, 2: 1-10.

Akomeah, P. A., Ekhator, O. and Udoka, C. (2010). Dry Season Phytoplankton Composition of Ibiekuma Dam, Ekpoma, Edo State. Ethiopian Journal of Environmental Studies and Management, 3(3). 3 (3): 36- 40.

Allan, J.D. (2001). Stream Ecology, structure and function of running waters. Shool of Natural Resources and Environment, University of Michigan, USA. Kluwer Academic Publishers. pp. 253.

American Public Health Association (APHA) (1985). Standard method for the examination of water and waste water, APHA, AWWA and WPCF, $16^{\text {th }}$ Edition, American Public Progress Springfield, New York. $958 \mathrm{pp}$

Chia, A. M. and Bako, S. P. (2008). Seasonal Variation of Cyanobacteria in Relation to Physcio-chemical Parameters of some Fresh Water Ecosystems in the Nigerian Guinea Savanna. Proceeding of Taal 2007: 12th World Lake Conference. Pp $1383-1387$.

Essien-lbok, M. A., Akpan, A.W., Udo, M. T., Chude, L. A., Umoh, I.A. and Asuquo, I.E. (2010). Seasonality in the Physical and Chemical characteristics of Mbo River, Akwa lbom State, Nigeria. Nigeria Journal of Agriculture, Food and
Environment. 6 (1-2):60-72.

Ezra A. G, (2006). Phyco- periphyton on some Aquatic Macrophytes in a Stream near Abubakar Tafawa Balewa University, Bauchi, Nigeria. Nigeria Journal of Experimental and Applied Biology.7(2).

Hsu, H. Y., Jeyashoke, N., Yeh, C. H., Song, Y. J., Hua, K. F. and Chao, L. K. (2009). Immuno-stimulatory bioactivity of algal polysaccharides from Chlorella pyrenoidosa activates macrophages via Toll-like receptor 4. Journal of Agricultural and Food Chemistry, 58(2): 927-936.

Jafari, N; Alavi, S.S (2010). Phytoplankton Community in relation to physic-chemical characteristics of thr Talar River, Iran. Journal of Applied Science Environmental Management, 14 (2) 51 56.

Kadiri, M. O. (1988) Ataxonomic Study of the Genus Closterium (Nitzsch) Ralf (Desmidiacene, Chlorophyta) in a small Nigerian Reservoir with Ecological Notes. Tropical Fresh Water Biology, 1:71-90.

Kadiri, M. O. (1993) Further Desmids from the Ikpoba Reservoir (Nigeria) Compared with other Records from Africa. Algological Studies, 71: 23-35.

Kadiri, M. O. (1996). More Desmids from the Ikpoba Reservoir, Nigeria. Comparison with other Africa Records. Algologica. 80: 87-98.

Kadiri, M. O. (2006) Phytoplankton Flora and Physicochemical Attributes of some waters in the Eastern Niger-Delta of Nigeria. Nigerian Journal of Botany, 19(2): 188-20.

Kemdirim, E.C. (2001): Checklist of Phytoplankton of Shendam Reservoir in Plateau State, Nigeria. Joumal of Aquatic Sciences, 16:61-63.

Khan, M.A., Fagbenu, T. and Ejike, C. (1983): Diurnal Variation of Physico-Chemical Factors and Planktonic Organisms in Jos, Plateau. (West African Water 
Reservoir). Journal of Limnology, 44: 6571.

Lackey, J. B. (1938). The manipulation and counting of river plankton and changes .in some organisms due to formalin preservation. U.S. Public Health Report. 63: 2080-2093.

Manoj, K. S. and Pooja, L. (2012). Structural and Physico-chemical Correlation of Algal Community of a Wetland Affected by Pulp and Paper Mill Effluents. Global Journal Inc. (US). pp. 256

Needham, J. G. and Needham, P.R., (1962). A Guide to the study of fresh water biology Holden-Day Inc. Yan Francisco 108Pp eIfe, Osun State. The Nigeria Field 57: $143-163$.

Nirmal K. J.J and Cini O. (2011). Phytoplankton Composition in relation to Hydrochemical properties of Tropical Community Wetland, Kanewal, Gujarat, India. Applied Ecology and Environmental Research 9 (3): 279-292

Odhiambo, W. and Gichuki, J. (1998): Seasonal Dynamics of the Phytoplankton Community in Relation to Environment in Lake Baringo, Kenya. African Journal of Tropical Hydrobiology and Fisheries, 8: 36-4.

Onyema, I. C. (2007). The phytoplankton Composition, Abundance and Temporal Variation of a Polluted Estuarine Creek in Lagos, Nigeria. Turkish Journal of Fisheries and Aquatic Sciences, 7: 8996.

Patrick, R. and Reimer, C. W. (1966). The diatoms of the United States Vols. 2 Moonegr. Academy of Natural Science. Philaphia.13

Pramila, K., Sharda, D., Chaudhari, P.R. and Waste, S.R. (2008): A Biomonitoring of Plankton to Asses Quality of Water in the Lakes of Nagpur City. The 12th World Lake Conference: 160-164.

Rabalais, N. N. (2002). Nitrogen in Aquatic Ecosystems. Bioone, 31: 102-112.

Rafia, R., Rouf A. B., Ashok, K. P. and
Samiullah, B. (2013). Ecological Study of Periphytic Algal Community of Doodh Ganga and Khansha-Mansha Streams of Yusmarg Forests: A Health Resort of Kashmir Valley, India. ECOLOGIA BALKANICA, 5(1): 9-19

Reynolds, C. S. (1984). The Ecology of freshwater plankton. Cambridge University Press, Cambridge. Pp 384.

Saktaywin, W., Tsuno, H., Nagare, H., Soyama, T. and Weerapakkaroon, J. (2005). Advanced sewage treatment process with excess sludge reduction and phosphorus recovery. Water Research. 39(5), 902-910.

Silva, E. I. L. (2004) Phytoplankton Characteristics, Trophic Evolution and Nutrient Dynamics in an Urban Eutrophic Lake: Kandy Lake in Sri Lanka. Restoration and Management of Tropical Eutrophic Lakes. Oxford and IBH Publishing, New Delhi.Pp. 219-260.

Silva, E. I. L. (2005) Ecology of phytoplankton in tropical waters: Introduction to the topic and ecosystem changes from Sri Lanka. Asian Journal of Water Environment and Pollution, 4: 25-35.

Verlencar, X. N. and Desai, S. (2004). Phytoplankton identification manual National Instituteof Oceanography. Dona panla Goa. Pp. 56.

World Health Organisation (2006). Guidelines for drinking water Quality. (2ed)(addendum to vol.1). Recommendations. WHO Press, Geneva Switzerland. Pp 595. 